\title{
PROBLEM-BASED GROUP DISCUSSION: AN EFFECTIVE ELT TECHNIQUE TO IMPROVE VOCATIONAL HIGH SCHOOL STUDENTS' TRANSACTIONAL SPEAKING SKILLS
}

\author{
Kaharuddin \\ Faculty of Education and Teacher Training, \\ Univerisitas Islam Negeri (UIN) Alauddin Makassar \\ E-mail: andi.kaharuddin@uin-alauddin.ac.id \\ Ananda Rahmadana \\ Faculty of Education and Teacher Training, \\ Univerisitas Islam Negeri (UIN) Alauddin Makassar \\ Anandarahmadana98@gmail.com
}

\begin{abstract}
In this millennial era, English speaking skills are very necessary for young learners, especially for Vocational High Schools students. However, few teachers still have difficulties in choosing the right technique to teach the speaking skills. Consequently, students feel that speaking is the hardest skill in English. This paper is aimed at discussing how to improve the students' transactional speaking skills (group discussion) using problem-based group discussion technique at Vocational High School 5 Gowa. A quantitative research design was used to carry out this study with support from the data collection instrument i.e. speaking video test (group discussion). The design of this study conducted using a quasi-experimental with nonequivalent control group design. Twenty (20) students in two classes i.e. ten students for the experimental class and ten students for the controlled class of the intermediate level were purposively selected to participate in this study. The results of this study showed that the problem-based group discussion technique is able to improve students' transactional speaking skills. It was proved by the result of the statistical analysis of the level significance $\mathrm{P}=0.05$ with the degree of freedom $(\mathrm{df})=9$ indicated that the t-test values of the students' transactional speaking skills (3.498) was higher than the t-table value (2.262). The outcome of this research indicates that this technique is effectively able to improve the students' transactional speaking skills in exchanging information, taking a part in formal discussions and even learning to work in real-life situations
\end{abstract}

Keywords: speaking skills; transactional speaking skills; problem-based group discussion

\section{INTRODUCTION}

As a foreign language in Indonesia, English is earnestly learnt by many people to have a good prospect in the international community. English has become an important subject as it is taught widely at formal school starting from elementary school up to higher education level; even in informal education, e.g. Center for language education (Yassi, A. H. Kaharuddin, 2018, Arafah, B., \& Kaharuddin, A. 2019). In academic world, English plays its decisive role in getting and sharing many kinds of knowledge from academic sessions such as seminars and conferences, especially at the international level (Bahar, A. K., \& Latif, I. 2019). It is widely known that English primarily has four kinds of skills, i.e. Speaking, Listening, Reading and Writing skill. Speaking skill is the most dominant skill learnt by many learners of English (Kaharuddin, A. 2019). It is even regarded as the hardest skill to be taught among EFL learners due to the complexity of its micro skills such as pronunciation, vocabulary, grammar, coherency, and fluency (Bahar, A. K. 2013, Zareie. 2014). In human social life, speaking has many functions depending on what the speaker 


\section{8 | JURNAL IHMU BUDAY}

Volume 8, Nomor 2, 2020

needs, such as to build social relations between two or more people, make social contact with people, or build a relationship (Kaharuddin, Hikmawati, Arafah, B. 2019, Arafah, B. \& Hasyim, M. 2019). Also, some people are involved in discussions with someone such as to seek or express opinions, to persuade someone about something, or to clarify information. Speaking not only functions as a medium to maintain social relations between participants but also functions as a medium for transacting messages being spoken, it is called transactional speaking skills (Bahar, A.K. 2014).

Speaking as a transaction refers to a situation where the focus is on what is said or done (Richards, 2015). According to Bahar, A.K, (2014), there are at least two types of transactional speaking skills, namely discussion, and interview. He further states that these skills are essential to be taught to Indonesian learners of English since knowledge of the skills enables the learners to take apart actively and effectively in transactional discourses such as discussions and interviews. The knowledge imparted during teaching the two skills will show the learners the nature of speaking in a formal discussion with others as well as the nature of communicating themselves verbally in a job interview. In this regard, it stands to reason for saying that transactional speaking skill is also one of the most important speaking skills to be taught among vocational high school students since this skill will help them to cope with difficulties regarding group discussions and interviews in their future job applications after graduating from the school.

Vocational High School 5 Gowa is one of vocational high schools that offers transactional speaking skills in its English curriculum. The skill is specifically given to in the third and fourth semester students at the second grade in that school. The purpose of offering transactional speaking skill is to equip the students with skills in speaking English in terms of mastering both casual and professional conversations, mastering transactional functions in formal and occupational speaking discourses such as asking and telling job descriptions, creating and receiving messages through direct interaction, expressing needs, giving instructions, giving opinions, giving advice and expressing approval and disagreement. Besides, the other purposes of teaching transactional speaking skill are to make the students able to observe (read) problems, to find solutions, to share and to retrieve information related to certain circumstances. However, students still encounter difficulties in reaching the purposes. The fact indicates that the students' score achievement is still under the Minimum Learning Mastery Standard. In this School, the Minimum Learning Mastery Standard is 75 points but the student score only has an average of 65 points, which means a low score (Surfiaty, interview, 2019). In short, the preliminary observation shows that the students are still unable to reach the Minimum Learning Mastery Standards due to their inability to perform things already set in the syllabus of English lesson, specifically in transactional speaking skills submaterials even if these skills have already been taught for some years in Junior and senior high school level.

In addition, the observation also indicates that one of contributing factors to the negative English learning outcome at the Vocational High School 5 Gowa is the teaching technique applied by the English teachers in teaching transactional speaking skills, in which the teachers still apply traditional techniques. Traditional technique refers to a way of teaching by directing the learners to listen and to memorize without giving the students opportunity to develop their critical thinking, problem solving ability, as well as the skills of making decision throughout 


\section{9 | JURNAL IHMU BUDAY}

Volume 8, Nomor 2, 2020

the lessons (Bahar, A.K. 2014). The fact is considered to be contradictory to the underlying principle of 2013 curriculum which has been implemented in that vocational high school.

For the reason, the researcher proposed an alternative technique to be applied in teaching transactional speaking skills which is here called problem-based group discussion. In this type of group discussion, all students in a group are given a short description of a situation (scenario) containing one or more problems which have to be solved by all the students in the group (Bahar, A.K. 2014, p. 85). Problem-based group discussion technique is believed able to encourage better integration between the ability to share information from the students' existing knowledge and the ability to produce new information by using their transactional speaking skills (Schmidt Henk et al., 2001, Bahar, K. 2013). Problems are good sources for making the learners to speak because while engaging in problems, they must use language to solve them (Kaharuddin, N. 2014, Hussain, 2018). The study has scientifically proved that this technique is able to improve the students' transactional speaking skills.

\section{LITERATURE REVIEW Transactional Speaking Skills}

Transactional speaking skill is one of speaking types that focuses on transacting messages with verbal skills to practice how to use speech, to share and get information without specifically being focused on establishing social relationships. Transactional conversations are conducted for information exchange, such as information-gathering interviews, role plays, or debates (Nuha, 2014, Kaharuddin, A., \& Latif, I. (2017). In our social life, transactional speech can be identified in terms of job interviews, discussions, etc. Two types of transactional speaking skills are often seen in our daily lives whether on TV programs or in employee recruitment. They discussed and interviewed. The two transactional discourse discussion aims to provide lessons to Indonesian students who learn English so that they can handle their speaking skills in group discussions and job interviews accurately and smoothly (Bahar, A.K. 2014).

Speaking as a transaction is easier to plan because communicative material is now a resource rich in group activities, information gap activities, and role plays that can provide resources for practicing ways of using speech to share and obtain information and to carry out real-world transactions. (Jack Richards, 2008) states that some of the skills involved in using conversation for a transaction are explaining a need or intention, explaining something, asking a question, confirming information, justifying an opinion, making a suggestion, clarifying understanding, making a comparison, agreeing and disagreeing. Discussions about transactional speaking skills are given by providing grammar rules and sample expressions. This is done to make students understand skills based on grammatical accuracy, morphological accuracy and syntax that are expected to make students fluent in using speaking skills.

\section{Problem-Based Group Discussion}

Nowadays, group discussions play an important role in teaching English, especially for speaking skills. Problembased group discussion technique is one type of group discussion that makes students express themselves in a case given by the teacher so that they will be able to study the problem and find a solution. Group discussion can be defined as a critical conversation about a particular topic, or maybe a series of topics, conducted in groups with a size that allows participants by all members (Bahar, A.K. 2014 , p. 44). The positive effect of group discussion is that dividing students into 
small groups seems to provide opportunities for students to become more actively involved in learning and for teachers to better monitor student progress.

Besides, (Brookfield, 2006) discusses disciplined states and focuses the exploration of shared concerns but without a predetermined endpoint for developing critical criticism, understanding information to increase self-criticism to encourage appreciation of diverse views to help people take informed action. (Wilkinson, 2016, Kaharuddin., \& Hasyim, M. 2020) classify types of discussion, they are; Problematic discussions focus on solutions to complex or simple problems where the teacher is dominant in the discussion; Dialectical discussion focuses on the expression, comparison, and refining of the viewpoints of students (and teachers) and students play a dominant role in the discussion; Information discussions focus on controversial issues in an atmosphere of acceptance and students have sufficient freedom to raise the issues they want to discuss.

This research focuses on how problem-based group discussions can improve students' transactional skills. Problem-solving activities encourage students to talk together to find solutions to (a set) problem or task (Setiadi, 2012). Students also support each other in learning when they make a commitment to solving shared problems through joint discussion and explanation. As a group, they identify relevant facts from problem scenarios, which help them better understand the problem (Zhang \& Lundeberg, 2014). Problems are designed to be scenarios by real-life cases to make students find solutions for it. Problembased discussion in small tutorial groups can be considered as an educational procedure, which aims to increase the interaction between the knowledge that is already available in participants and new information that must be learned (Schmidt
Henk et al., 2001). According to Bahar, A.K. (2014) problem-based group discussions are often carried out using several systematic procedures among other things: studying problems provided in a scenario, analyzing the problems, formulating and discussing possible solutions to the problems, and determining possible solutions.

\section{METHODOLOGY}

This study was conducted using quantitative research. Quantitative research methods are research methods dealing with numbers and anything measurable in a systematic way of investigation of phenomena and their relationships (Perumal, 2014, Kaharuddin, K. 2016). The design of this study used a quasi-experimental design with nonequivalent control group design which was separated into the two classes, the experimental and controlled class and used the pre-test and the post-test design.

The population of this study was all of the students in the second grade of Vocational High School 5 of Gowa include 5 majors (TKJ, UPW, TKR, TITL, TKB). There were 156 Students. The researcher employed a purposive sampling technique. Purposive sampling is done only on the basis of consideration of the researcher who considers the desired elements already in the members of the sample taken (Nasution, 2003). The purposive sampling was used by the researcher because the researcher had special considerations in taking samples based on the lesson plan and interview from the teacher about the scores of these students. Therefore, the sample of this study was two classes in second-grade students at Vocational High School 5 of Gowa, XI TKJ and XI UPW include twenty students with four group discussions. The researcher chose twenty students in two classes because their score was too low according to the 


\section{1 | JURNAL ILMU BUDAYA}

Volume 8, Nomor 2, 2020

recommendation by the teacher based on the interview.

In this case, the researcher used a speaking test to measure the pre-test and post-test of the students by the rating scale of speaking for a low intermediate level (Heaton, 1975). The researcher asked the students to make the video speaking tests i.e. group discussion. Speaking videos of group discussion tests were considered the right instrument to measure the students'
E-ISSN: 2621-5101 P-ISSN:2354-7294

transactional speaking skills. For the quantitative data analysis technique, the researcher used SPSS to make the data is easy to analysis, SPSS standing for Statistical Package for the Social Sciences. Statistical Package for the Social Sciences is a commercially distributed software suite for data management and statistical analysis (Frey, 2017). Here was the classifying of students' score in speaking test, there are six classifications follows:

\begin{tabular}{lll}
\hline Score & Score Ranges & Classification \\
\hline $\mathbf{6}$ & $16.00-18.00$ & Excellent \\
$\mathbf{5}$ & $13.00-15.99$ & Very good \\
$\mathbf{4}$ & $10.00-12.99$ & Good \\
$\mathbf{3}$ & $7.00-9.99$ & Average \\
$\mathbf{2}$ & $4.00-6.99$ & Poor \\
$\mathbf{1}$ & $1.00-3.99$ & Very Poor \\
\hline
\end{tabular}

(Yassi, A. H. Kaharuddin, 2018: 188)

\section{FINDING AND DISCUSSION}

\section{The Result of Pre-test and Post-test of Controlled Class}

TABLE 1. The Result of Pre-test of Controlled Class

\begin{tabular}{lccccc}
\hline No & $\begin{array}{c}\text { Respondent } \\
\text { Number }\end{array}$ & \multicolumn{3}{c}{ Speaking Components } & Total \\
\cline { 3 - 6 } & 01 & Accuracy & Fluency & Comprehensibility & \\
\hline 1. & 01 & 3 & 2 & 7 \\
\hline 2. & 02 & 3 & 3 & 2 & 8 \\
\hline 3. & 03 & 1 & 2 & 1 & 4 \\
\hline 4. & 04 & 1 & 2 & 1 & 4 \\
\hline 5. & 05 & 0 & 0 & 0 & 0 \\
\hline 6. & 06 & 2 & 3 & 2 & 7 \\
\hline 7. & 07 & 2 & 2 & 2 & 6 \\
\hline 8. & 08 & 2 & 3 & 2 & 7 \\
\hline 9. & 09 & 0 & 0 & 0 & 0 \\
\hline 10. & 10 & 0 & 0 & 0 & 0 \\
\hline & Average & 1.3 & 1.8 & 1.2 & $\mathbf{4 . 3}$ \\
\hline
\end{tabular}

\begin{tabular}{ccccc}
\hline No $\begin{array}{c}\text { Respondent } \\
\text { Number }\end{array}$ & \multicolumn{3}{c}{ Speaking Components } & Total \\
\cline { 2 - 5 } & Accuracy & Fluency & Comprehensibility & \\
\hline 01 & 2 & 3 & 2 & 7 \\
\hline 02 & 3 & 3 & 3 & 9 \\
\hline 03 & 1 & 2 & 1 & 4 \\
\hline 04 & 0 & 0 & 0 & 0 \\
\hline 05 & 0 & 0 & 0 & 0 \\
\hline 06 & 3 & 3 & 3 & 9 \\
\hline 07 & 2 & 3 & 2 & 7 \\
\hline 08 & 2 & 2 & 2 & 6 \\
\hline 09 & 1 & 2 & 2 & 5 \\
\hline 10 & 2 & 2 & 2 & 6 \\
\hline Average & 1.6 & 2 & 1.7 & $\mathbf{5 . 3}$
\end{tabular}


Based on the result of the controlled class pre-test analysis in the table above, it has been found that the total score of this test ranges from 1.00 to 18.00 . The highest total score was achieved by respondent number 02 with 8 total scores. On the other hand, the lowest total score was achieved by respondent number 05,09 and 10 with zero (0) score. However, the overall students achieved 4.3 as the average score for their transactional speaking skills which means poor, because the score ranges for poor classification was $4.00-6.99$.

Based on the result of the controlled class post-test analysis in the table above, it has been found that the highest total score was achieved by respondent number 02 with 9 total score. On the other hand, the lowest total score was achieved by respondent number 04 and 05 with still zero (0) score. However, the overall students achieved 5.3 as the average score for their transactional speaking skills which means still poor and there was no improvement from pre-test to post-test in controlled class. The result of controlled class was also processed and analyzed by using SPSS which had eventually resulted in the following description:

Descriptive Statistics

\begin{tabular}{cc|c|c|c|c|c} 
& $\mathrm{N}$ & Minimum & Maximum & Mean & Std. Deviation & Variance \\
\hline Pretest & 10 & .00 & 8.00 & 4.3000 & 3.23351 & 10.456 \\
\hline Postest & 10 & .00 & 9.00 & 5.3000 & 3.19896 & 10.233 \\
\hline $\begin{array}{c}\text { Valid N } \\
\text { (listwise) }\end{array}$ & 10 & & & & & \\
\hline & & & & & & \\
\hline
\end{tabular}

The description of the pre-test and post-test of controlled class can also be seen in the following statistical histogram which was processed by using SPSS as well.

\section{The Result of Pre-test and Post-test of Experimental Class}

TABLE 3. The Result of Pre-test of Experimental Class

\begin{tabular}{cccccc}
\hline No & $\begin{array}{c}\text { Respondent } \\
\text { Number }\end{array}$ & \multicolumn{3}{c}{ Speaking Components } & Total \\
\cline { 3 - 6 } & Accuracy & Fluency & Comprehensibility & \\
\hline 1. & 001 & 3 & 3 & 3 & 9 \\
\hline 2. & 002 & 2 & 3 & 3 & 8 \\
\hline 3. & 003 & 1 & 2 & 1 & 4 \\
\hline 4. & 004 & 2 & 2 & 2 & 6 \\
\hline 5. & 005 & 0 & 0 & 0 & 0 \\
\hline 6. & 006 & 2 & 2 & 1 & 5 \\
\hline 7. & 007 & 1 & 2 & 1 & 4 \\
\hline 8. & 008 & 1 & 2 & 1 & 4 \\
\hline 9. & 009 & 1 & 2 & 1 & 4 \\
\hline 10. & 010 & 1 & 2 & 1 & 4 \\
\hline \multicolumn{2}{l}{ Average } & 1.4 & 2.0 & 1.4 & 4.8 \\
\hline
\end{tabular}




\section{3 | JURNAL ILMU BUDAYA}

Volume 8, Nomor 2, 2020

E-ISSN: 2621-5101 P-ISSN:2354-7294

Based on the result of the experimental

achieved by respondent number 05 with a

\begin{tabular}{|c|c|c|c|c|c|}
\hline \multirow[t]{2}{*}{ No } & \multirow{2}{*}{$\begin{array}{c}\text { Respondent } \\
\text { Number }\end{array}$} & \multicolumn{3}{|c|}{ Speaking Components } & \multirow[t]{2}{*}{ Tota } \\
\hline & & Accuracy & Fluency & Comprehensibility & \\
\hline 1. & 001 & 3 & 3 & 3 & 9 \\
\hline 2. & 002 & 4 & 4 & 4 & 12 \\
\hline 3. & 003 & 2 & 2 & 2 & 6 \\
\hline 4. & 004 & 2 & 2 & 2 & 6 \\
\hline 5. & 005 & 2 & 2 & 2 & 6 \\
\hline 6. & 006 & 3 & 3 & 3 & 9 \\
\hline 7. & 007 & 2 & 2 & 2 & 6 \\
\hline 8. & 008 & 1 & 2 & 1 & 4 \\
\hline 9. & 009 & 2 & 2 & 2 & 6 \\
\hline 10. & 010 & 2 & 2 & 2 & 6 \\
\hline \multicolumn{2}{|c|}{ Average } & 2.3 & 2.4 & 2.3 & 7.0 \\
\hline
\end{tabular}

class pre-test analysis in the table above, it has been found that the total score of this test ranges from 1.00 to 18.00 . The highest total score was achieved by respondent number 01 with 9 total scores. On the other hand, the lowest total score was

The result of experimental class post-test analysis as shown in the table above, indicates that the highest total score was achieved by respondent number 02 with 12 total score. On other hand, the lowest total score was achieved by respondent number 08 with still 4 score. Therefore, the overall students achieved zero (0) score. However, the overall students achieved 4.8 as the average score for their transactional speaking skills which means poor, because the score ranges for poor classification was $4.00-$ 6.99 .

7.0 as the average score for their transactional speaking skills which means fair and there was any improvement from pre-test to post-test in experimental class.

The result of experimental class was also processed and analyzed by using SPSS which had eventually resulted in the following the description:

Descriptive Statistics

\begin{tabular}{lr|r|r|r|r|r} 
& N & Minimum & Maximum & Mean & Std. Deviation & Variance \\
\hline Pretest & 10 & .00 & 9.00 & 4.8000 & 2.48551 & 6.178 \\
\hline Postest & 10 & 4.00 & 12.00 & 7.0000 & 2.30940 & 5.333 \\
\hline $\begin{array}{l}\text { Valid N } \\
\text { (listwise) }\end{array}$ & 10 & & & & & \\
\hline
\end{tabular}

The description of the pre-test and post-test of experimental class can also be seen in the following statistical histogram which was processed by using SPSS as well.

\section{The Overall Results of Pre-test and Post-test Experimental Class}

The results of the pre-test and the post-test in the experimental class are used to show the improvement of the students score. In the pretest, the students are asked by the researcher to make the video transactional speaking skills test i.e. group discussion before the intervention began. After giving the course, the students are ordered to make the new video of group discussion to see whether the intervention was successful in improving of the gain scores between pre-test and post-test in experimental class can be illustrated as follows: 
Table 5 The Overall Result of the Pre-test and the Post-test of Experimental Class

\begin{tabular}{cccc} 
& & \multicolumn{2}{c}{ Total Pre and Post Test Scores } \\
\cline { 3 - 4 } No & Respondent Number & Pre-test & Post-test \\
\cline { 3 - 4 } $\mathbf{1}$ & 01 & 9 & 9 \\
\hline $\mathbf{2}$ & 02 & 8 & 12 \\
\hline $\mathbf{3}$ & 03 & 4 & 6 \\
\hline $\mathbf{4}$ & 04 & 6 & 6 \\
\hline $\mathbf{5}$ & 05 & 0 & 6 \\
\hline $\mathbf{6}$ & 06 & 5 & 9 \\
\hline 7 & 07 & 4 & 6 \\
\hline $\mathbf{8}$ & 08 & 4 & 4 \\
\hline $\mathbf{9}$ & 09 & 4 & 6 \\
\hline $\mathbf{1 0}$ & 10 & 4 & $\mathbf{7 . 0}$ \\
\hline & Average & 4.8 & Fair \\
\hline
\end{tabular}

The table shows that there is a significant improvement from pre-test to post-test after giving an intervention. It means that the students get improvement in their transactional speaking skills after learning problem-based group discussion. The improvement can be measured by taking a look at the minimum and the maximum scores in the pre-test and the post-test in which zero (0) is the minimum score for the pre-test while four (4) is the minimum score in the post-test. On the other hand, nine (9) is the maximum score in the pre-test, while twelve (12) is the maximum score in the post-test.

In addition, the students' progress in the learning can also be measured by comparing the score in the pre-test 4.8 and 7.0 in the post-test. Therefore, the researcher may then state that the quality of students' transactional speaking skill improves from poor to fair. The data above were also processed by using SPSS which result in the presentation of Box Plots.

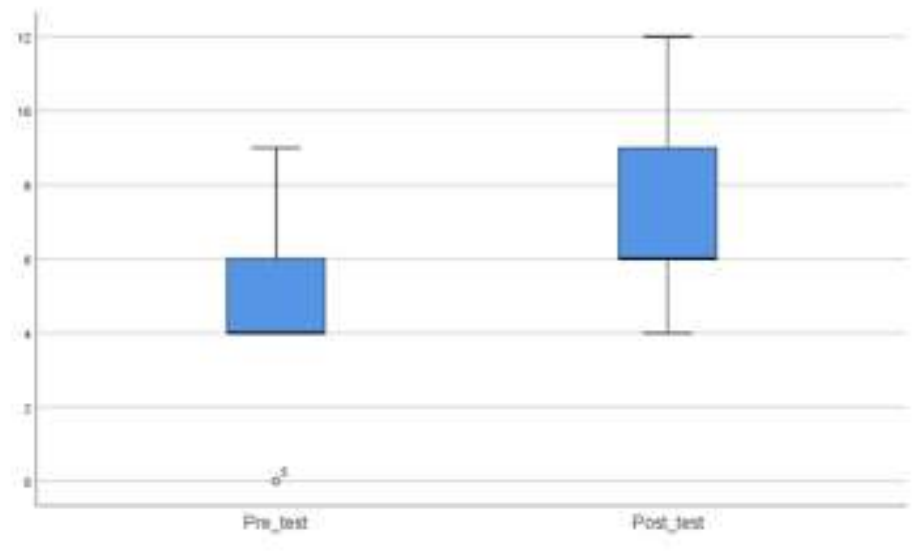

Figure 1 The Comparison between the Pre-test and Pos-test Scores Distribution

\section{Assumption Test}

Before testing this research hypothesis, it is necessary to test the sample distribution to find out whether the sample is normal or non-normal. The name of that test is the normality test. H0 (The null hypothesis) : The sample has normal distribution when the significance
The normality test is aimed at testing all hypothesis tests which tests a null against an alternative hypothesis. The result of the normality test deals with the statements of hypothesis namely:

value is greater than 0.05 ( $\mathrm{sig}>0.05) . \mathrm{H} 1$ (The alternative hypothesis) : The sample 


\section{5 | JURNAL IHMU BUDAYA}

Volume 8, Nomor 2, 2020

is not normally distributed when significance is less than 0.05 ( $\mathrm{sig}<0.05)$

To test the normality of sample distribution, this research used the output of SPSS as follows:

One-Sample Kolmogorov-Smirnov Test

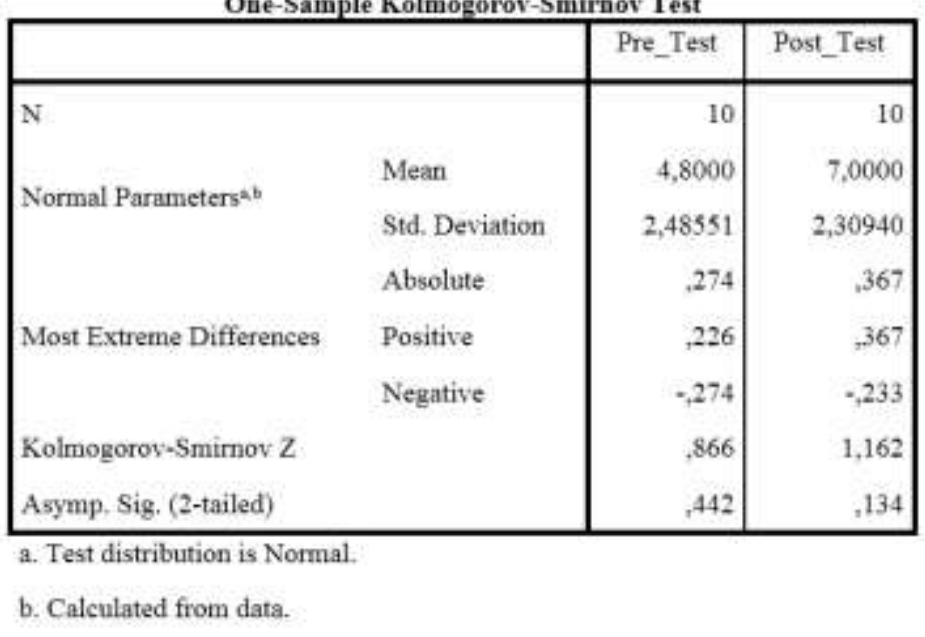

From the table above, the significant value of the pre-test $=0.442>$ 0.05 and the post-test $=0.134>0.05$. It means that the samples are normally distributed.

\section{Independent $\mathbf{T}$ test}

After finding out that the samples of the pre-test and post-test are normally

distributed, the implication of this research are:

If Sig. (2-tailed) < 0.05, H0 is rejected and $\mathrm{H} 1$ is accepted

If Sig. (2-tailed) $<0.05, \mathrm{H} 0$ is accepted and $\mathrm{H} 1$ is rejected

In order to test the hypothesis, the independent t-test is used to know whether $\mathrm{H} 0$ or $\mathrm{H} 1$ is accepted or not.

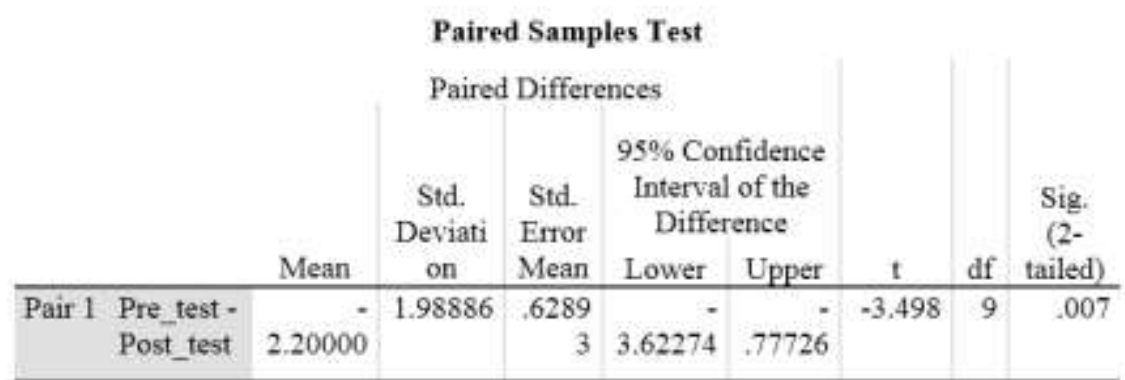

Based on the table above it is found out that SPSS output for one sample T-test $=3.498$ and $\operatorname{sig}(2$ tailed $)=0.007$. This output reveals that sig $=0.007<\mathrm{p}$-value $=$ 0.05 . This implies that the intervention has significant main effect on the students' transactional speaking skills improvement. Therefore, the null hypothesis is rejected.
On the other hand, to tests the hypothesis can be known by using the distribution table. Where the distribution table shows that the t-test value is greater than t-table. It indicated that there was a significant difference between before and after giving the intervention. The statement was proved by the t-test value (3.498) which was higher than t-table 


\section{6 | JURNAL ILMU BUDAYA}

Volume 8, Nomor 2, 2020

(2.262) in the distribution table, at the level of significance 0.05 and degree of CONCLUSION

Problem-based group discussion technique is effective to improve transactional speaking skills than the conventional technique. In the controlled class, students were only trapped in the classification of the score "Poor" which is 4.3 average scores in the pre-test and 5.3 in the post-test. It means there was no improvement from those students. In the experimental class, students have an increase in transactional speaking skills after being given an intervention i.e. 5.3 average scores in the pre-test and 7.0 in the post-test. The classification score was from the "poor" to "fair", it means there was an improvement from the students.

It was found out that T-test $=3.498$ and sig $(2$ tailed $)=0.007$. This output reveals that sig $=0.007<\mathrm{p}$-value $=0.05$. This implied that the intervention has a significant main effect on the students' transactional speaking skills improvement. Therefore, the alternative hypothesis was accepted. Besides, to tests, the hypothesis could be known by using the distribution table. Where the distribution table shows that the t-test value was greater than $\mathrm{t}$ table. It indicated that there was a significant difference between before and after giving the intervention. The statement was proved by the t-test value (3.498) which was higher than t-table (2.262) in the distribution table, at the level of significance 0.05 and degree of freedom (df) 9.

The finding of this study indicated that the problem-based group discussion technique helps the students to improve their transactional speaking skills in exchanging information, taking a part in formal discussions and even learning to work in real-life situations.

\section{REFERENCES}

Andi, K., \& Arafah, B. (2017). Using
E-ISSN: 2621-5101 P-ISSN:2354-7294

freedom (df) 9.

needs analysis to develop English teaching materials in initial speaking skills for Indonesian college students of English. The Turkish Online Journal of Design, Art and Communication (TOJDAC), Special Edition, 419-436

Arafah, B., \& Kaharuddin, A. (2019). The Representation of Complaints in English and Indonesian Discourses. Opción, 35, 501-517.

Arafah, B., \& Hasyim, M. (2019). The Language of Emoji in Social Media. KnE Social Sciences, 494-504.

Bahar, A. K. (2013). The Communicative Competence-Based English Language Teaching. Yogyakarta: TrustMedia.

Bahar, A.K (2014). Transactional Speaking Skills: A Guide to Improve Transactional Exchange Skills in English for Group Discussions $(G D)$ and Interviews. Gowa: Gunadarma Ilmu.

Bahar, K. (2013). The Communicative Grammar Translation Method: An Integrated Method of CLT and GT for Teaching English Communicatively and Accurately. Yogyakarta: Trustmedia.

Bahar, K. (2014). Interactional Speaking a Guide to enchance Natural Communication Skills in English. Yogyakarta: TrustMedia Ethnologue.

Bahar, A. K., \& Latif, I. (2019). Societybased English community (SOBAT): EFL learners'strategy in learning and practicing English outside the walls. Jurnal ilmu budaya, 7(2), 255-265.

Brookfield, S. D., \& Preskill, S. (2016). The discussion book: 50 great ways to get people talking. John Wiley \& Sons.

Frey, F. (2017). SPSS (Software). The International Encyclopedia of Communication Research Methods, 1-2.

Hussain, S. (2018). Teaching Speaking 
Skills In Communication Classroom. ResearchGate

(https://www. researchgate. net publication).

Heaton, J. B. (1975). Writing English language tests: A practical guide for teachers of English as a second or foreign language. Longman Publishing Group.

Kaharuddin, Hikmawati, Arafah, B. (2019). Needs Analysis on English for Vocational Purpose for Students of Hospitality Department. KnE Social Sciences, 344-387.

Kaharuddin, N. (2014). The Problems of Indonesian College EFL Learners in Listening Comprehension. Jurnal Ilmu Budaya, 2(2).

Kaharuddin, K. (2016). Detecting Errors in English Made by Intermediate Indonesian Learners of English in English Department Students of STAIN PAREPARE. KURIOSITAS: Media Komunikasi Sosial Keagamaan, 9(1), 1-19.

Kaharuddin, A., \& Latif, I. (2017). The Essential of Discourse Analysis for Teachin English as a Foreign Language.

Kaharuddin, A. (2018). The Communicative Grammar Translation Method: A Practical Method to Teach Communication Skills of English. ETERNAL (English, Teaching, Learning, and Research Journal), 4(2), 232-254.

Kaharuddin, A. (2019). The Power of English: Recognizing and Utilizing The Tremendous Impact Of The English Language On The Community. English Language Teaching for EFL Learners, 1(1), 3948.

Kaharuddin., \& Hasyim, M. (2020). The Speech Act of Complaint: SocioCultural Competence Used by Native Speakers of English and Indonesian. International Journal of Psychosocial
Rehabilitation, 24(6), 14016-14028. doi: 10.37200/ijpr/v24I6/pr261351

Nasution, R. (2003). Teknik Pengambilan Sampling. Fakultas Kesehatan Masyarakat Universitas Sumatra Utara, 1, 1-7.

Nuha, U. (2014). Transactional and Interpersonal Conversation Texts in English Textbook. Register Journal, 7(2), 205-224.

Richards, J. C. (2008). Teaching listening and speaking. Cambridge, England: Cambridge university press.

Richards JC. (2015). Developing classroom speaking activities: From theory to practice. GuidelinesSingapore-Periodical for Classroom Language Teachers then Magazine for Language Teachers. 2;28(2):3.

De Grave, W. S., Schmidt, H. G., \& Boshuizen, H. P. (2001). Effects of problem-based discussion on studying a subsequent text: A randomized trial among first year medical students. Instructional Science, 29(1), 33-44.

Setiadi, M. A. (2012). Using Communicative Language Teaching (Clt) Approach Through Small Group Discussion as a Device to Stimulate the Students to Speak in English. Exposure, 1(2), 223-233.

Wilkinson, K., \& Barter, P. (2016). Do mobile learning devices enhance learning in higher education anatomy classrooms?. Journal of Pedagogic Development, 6(1), 14-23.

Yassi, A. H. Kaharuddin (2018). Syllabus Design Of English Language Teaching. Jakarta: Prenada Media.

Zareie, B., Gorjian, B., \& Pazhakh, A. (2014). The effect of interactional and transactional speaking strategies on teaching speaking skills to Iranian EFL learners at senior high school level. International Journal of Language Learning and Applied Linguistics World (IJLLALW), 5(2), 443-459. 


\section{8 | JURNAL IHMU BUDAYA}

Volume 8, Nomor 2, 2020

E-ISSN: 2621-5101 P-ISSN:2354-7294

Zhang, M., Lundeberg, M., \& Eberhardt, J. (2011). Strategic facilitation of problem-based discussion for teacher professional development. Journal of the learning sciences, 20(3), 342-394. 